\title{
ATYPICAL DISSEMINATED CUTANEOUS HISTOPLASMOSIS IN AN IMMUNOCOMPETENT CHILD, CAUSED BY AN “ABERRANT" VARIANT OF Histoplasma capsulatum var. capsulatum
}

Carlos da Silva LACAZ(1), Gilda Maria Barbaro DEL NEGRO(1), Mônica Scarpelli Martinelli VIDAL(1), Elisabeth Maria HEINS-VACCARI(1), Roseli Freitas dos SANTOS(1), Marilena A. MARTINS(2), Marcia M. OZAKI(3), Ricardo ROMITI(3), Ricardo PROENÇA(3) \& Luiz Guilherme Martins de CASTRO(3)

\section{SUMMARY}

A case of atypical disseminated cutaneous histoplasmosis in a five-year old, otherwise healthy child, native and resident in São Paulo metropolitan area is reported. Cutaneous lesions were clinically atypical. Histologic examination disclosed a granulomatous reaction but no fungal structures could be demonstrated by specific staining nor by immunohistochemical reaction. The fungus was isolated from biopsy material on two different occasions, confirming diagnosis of an unusual fungal infection. The fungus, originally thought to be a Sepedonium $s p$. due to the large sized, hyaline or brownish colored tuberculated macroconidia and to lack of dimorphism (yeast form at $37^{\circ} \mathrm{C}$ ) produce $\mathrm{H}$ and $\mathrm{M}$ antigens, visualized by the immunodiffusion with rabbit anti-Histoplasma capsulatum hyperimmune serum. Patient's serum sample was non reactive with $H$. capsulatum antigen by immunodiffusion, counterimmunoelectrophoresis and complement fixation tests, and immunoenzymatic assay failed to detect the specific circulating antigen. This serum was tested negative by double immunodiffusion when antigen obtained from one of the isolated samples was used. Both cultures were sent to Dr. Leo Kaufman, Ph.D. (Mycoses Immunodiagnostic Laboratory, CDC-Atlanta/USA), who identified them as $H$. capsulatum by the exoantigen and gen-probe tests. Both clinic and mycologic characteristics of the present case were atypical, suggesting the fungus isolated is an "aberrant variant" of $H$. capsulatum var. capsulatum, as described by SUTTON et al. in $1997^{19}$. Treatment with itraconazole $100 \mathrm{mg}$ /day led to cure within 90 days

KEYWORDS: Histoplasma capsulatum; Cutaneous histoplasmosis; Aberrant strain.

\section{INTRODUCTION}

Classic histoplasmosis also called as Darling's disease, is caused by Histoplasma capsulatum var. capsulatum. The association histoplasmosis-AIDS (WHEAT et al., 1990 ${ }^{20}$; ROCHA \& SEVERO, $1994^{16}$; ALVES, 1996 ${ }^{1}$; BORGES et al., 1997 ${ }^{3}$ ) became so frequent that this fungal infection was included in the definition of diagnostic criteria of this immunodeficiency syndrome by the CDC. The usual clinical manifestation is an acute self limited lung disease. However, immunosuppressed patients may develop systemic infection with hepatoesplenomegaly, skin lesions, diffuse lung infiltrates and pancitopenia. In African histoplasmosis, caused by $H$. capsulatum var. duboisii, cutaneous lesions such as large abscesses predominate and pulmonary compromise is rare. Asymptomatic histoplasmosis infection can be detected by positive intradermal test with histoplasmin, an antigen which possesses both $\mathrm{H}$ and $\mathrm{M}$ antigenic fractions.In 1976 STANDARD \& KAUFMAN $^{17}$ standardized immunochemical tests to differentiate both varieties of $H$. capsulatum. The authors performed double immunodiffusion (DID) using serum obtained from hyperimmune rabbits and standard sample antigens. PADHYE et al. ${ }^{14}$ developed a specific DNAprobe which is being currently used for diagnostic purposes. The present paper presents an atypical case of disseminated cutaneous histoplasmosis in a 5 year-old immunocompetent child. Specific antibodies and circulating polysaccharide antigens were not detected in this patient's serum. No fungal structures were observed in histologic examination of cutaneous lesions.

Fungal samples were isolated from biopsy material in two different times. Both samples were identified as $H$. capsulatum var. capsulatum by means of specifc exoantigen test and gen-probe assay.

\section{CASE REPORT}

A 5 year-old, Caucasian child, native and resident in São Paulo metropolitan area was admitted at the Dermatology Clinic of "Hospital das Clinicas", University of São Paulo, presenting $5 \mathrm{~mm}$, erythematoviolaceous, slightly infiltrated cutaneous nodules, surrounded by a hypocromic halo. Lesions had been present for approximately 18 months and were first noted on the buttocks (Fig. 1). During the next few months

(1) Laboratório de Micologia Médica do Instituto de Medicina Tropical de São Paulo and LIM 53/HCFMUSP, São Paulo, SP, Brasil.

(2) Seção de Micologia do Instituto Adolfo Lutz, São Paulo, SP, Brasil

(3) Divisão de Dermatologia/Faculdade de Medicina da Universidade de São Paulo, São Paulo, SP, Brasil.

Correspondence to: Prof. Dr. C.S. Lacaz, Laboratório de Micologia Médica do Instituto de Medicina Tropical de São Paulo. Av. Dr. Enéas Carvalho de Aguiar 500, andar térreo, 05403-000 São Paulo, SP, Brasil. Phone: 55113066 7443, FAX: 5511852 3622; e-mail: valacaz@usp.br 


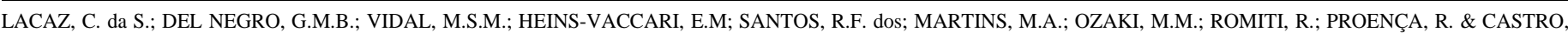

L.G.M. de - Atypical disseminated cutaneous histoplasmosis in an immunocompetent child, caused by an "aberrant" variant of Histoplasma capsulatum var. capsulatum. Rev. Inst. Med. trop. S. Paulo, $41(3):$ 195-202, 1999

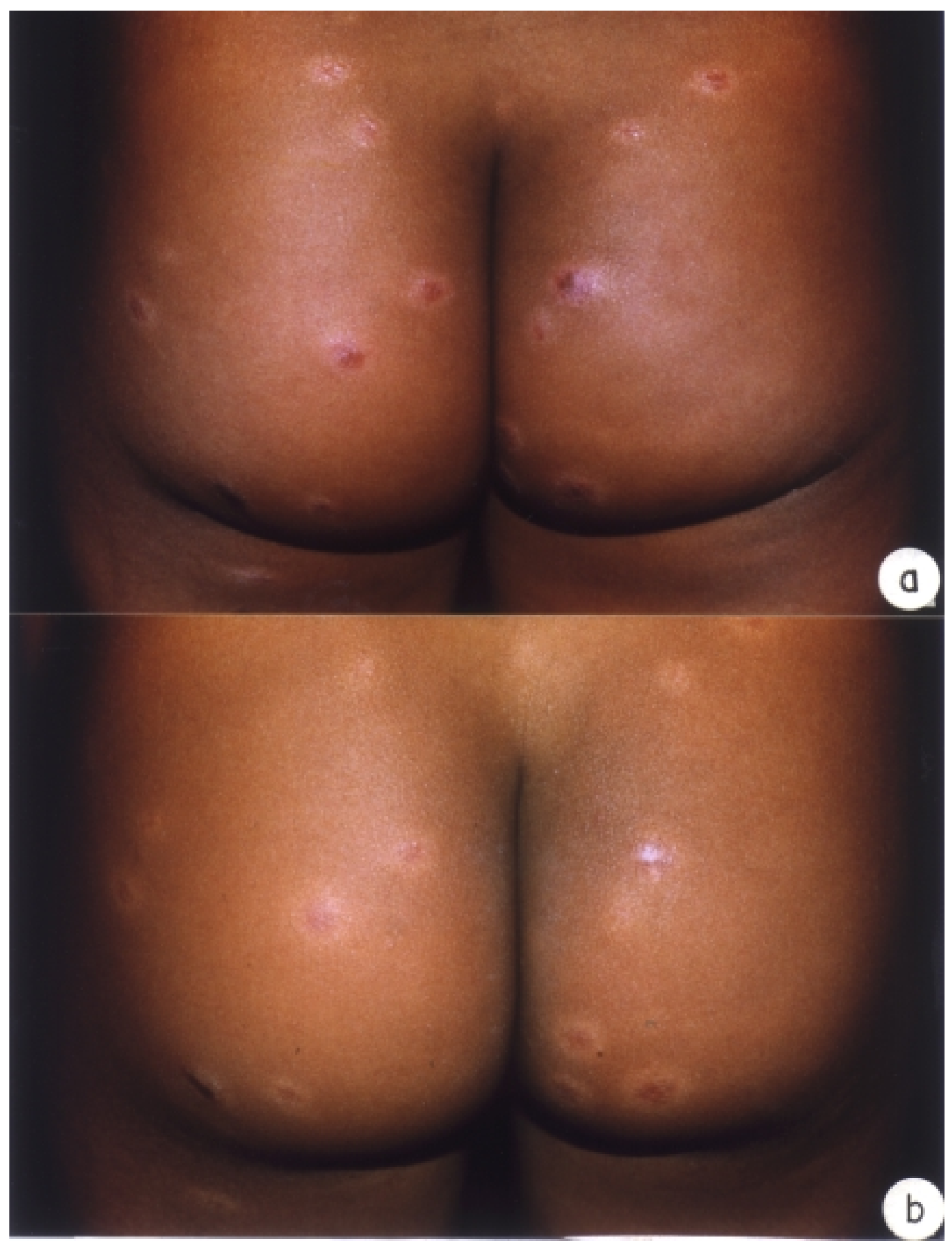

Fig. 1 - Patient G.M.L. Before (a) and after (b) treatment.

lesions progressively extended to upper limbs (Fig. 2), outer ears (Figs. 3 and 4), face and knees. Except for fever at the onset of the disease, no systemic signs nor symptoms were observed.
Physical examination of this child showed an otherwise healthy and weighted $21 \mathrm{~kg}$. Chest X-ray and abdominal ultrasonography were normal, as well as blood biochemistry exams and blood cell count. 


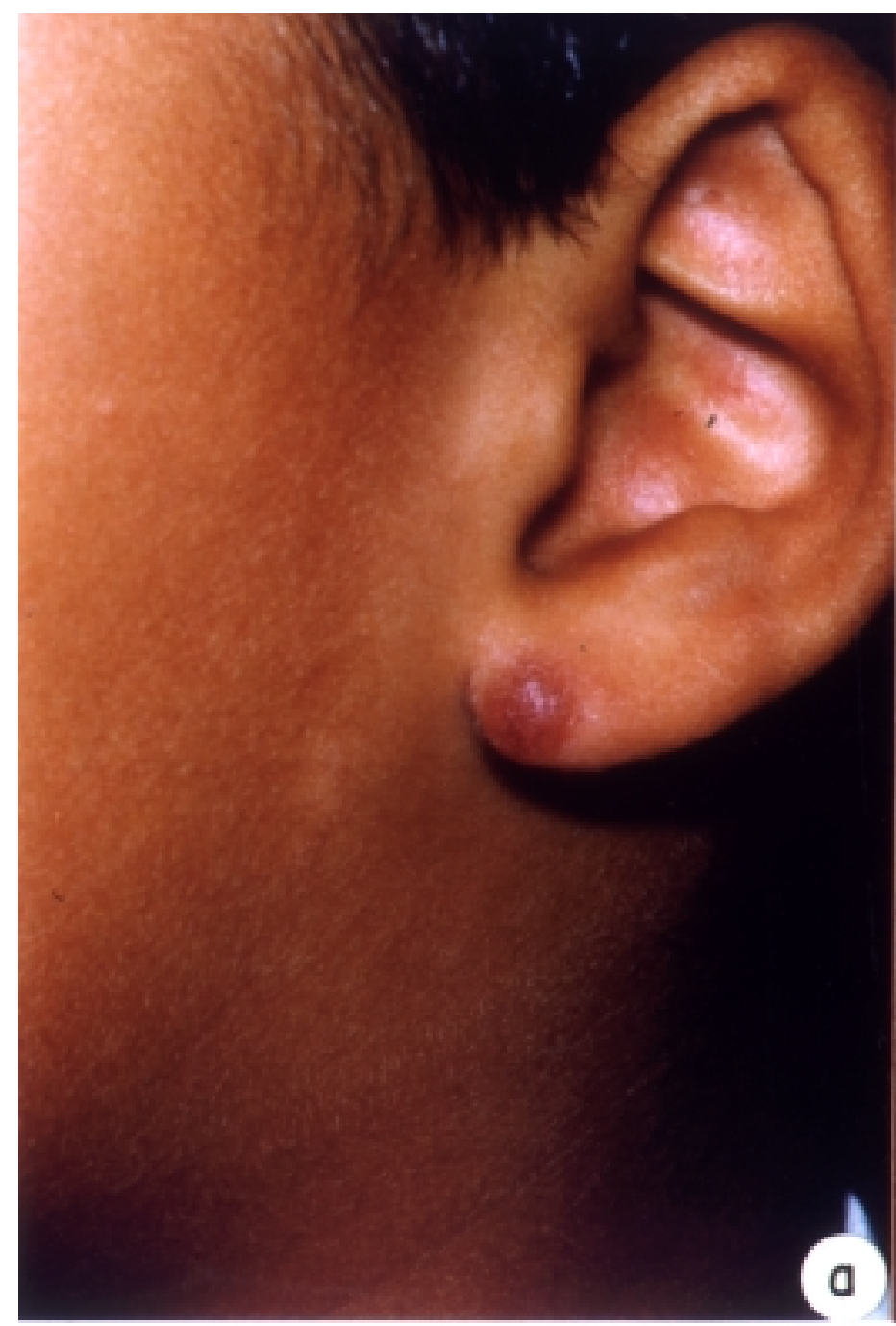

Fig. 2 - Patient G.M.L. Before (a) and after (b) treatment.

Clinical diagnosis included numular eczema, lymphomatoid papulosis, sarcoidosis and persistent reaction due to insect bite.

Histologic examination of five different lesions, excised on different occasions, disclosed similar findings (Fig. 5), i.e. acanthosis, spongiosis and lymphocyte exocytosis. Intense dermal inflammatory infiltrate with casts of epithelioid and multinucleated Langhan's giant cells, surrounded by a variable number of lymphocytes, characterizing a granulomatous response was present. Grocott and acid-fast stainings, as well as immunohistochemical $\mathrm{ABC}$-peroxidase reaction using antibodies against $H$. capsulatum antigens resulted negative in all specimens. Diagnosis of a chronic granulomatous dermatitis was established, leading to new diagnostic hypothesis: paucibacillar leprosy, sarcoidosis, cutaneous tuberculosis, cutaneous T-cell lymphoma "slack skin" type and some kind of deep seated mycosis.

Mitsuda (10 x $10 \mathrm{~mm})$, histoplasmin $(10 \times 7 \mathrm{~mm})$ and candidin $(7 \mathrm{x}$ $5 \mathrm{~mm}$ ) reactions were positive, while PPD, Montenegro's and trichophytin reactions were negative. Antibody detection tests (double immu-

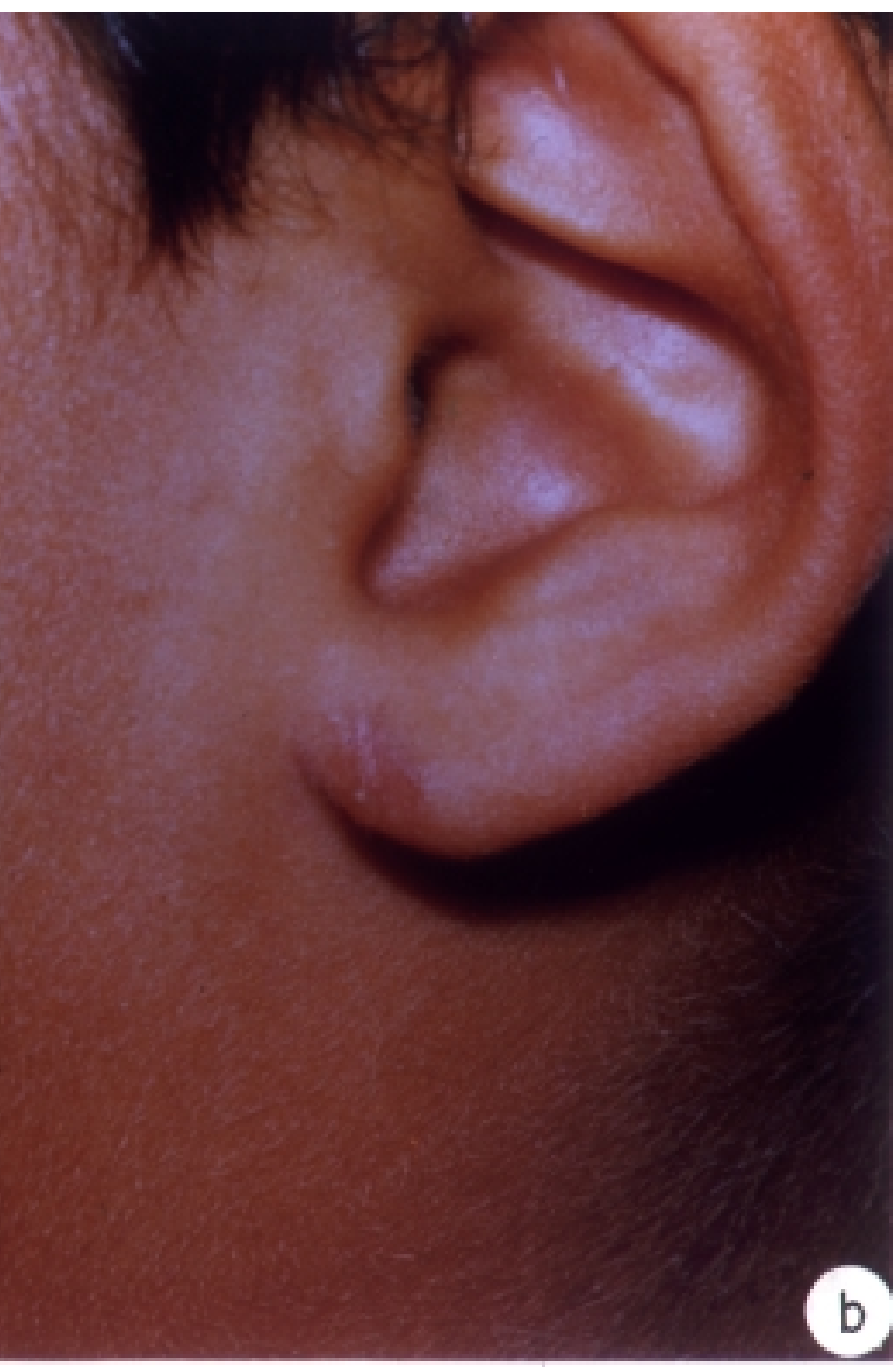

nodiffusion and counterimmunoelectrophoresis) for Paracoccidioides brasiliensis, Histoplasma capsulatum and Aspergillus fumigatus were negative.

Two different biopsy specimens grew on Sabouraud agar, on different times, a white cotton-like colony. The fungus, originally thought to be a Sepedonium sp. sample due to the large sized, hyaline or brownish colored tuberculated macroconidia and to lack of dimorphism $\left(37^{\circ} \mathrm{C}\right)$ produced $\mathrm{H}$ and $\mathrm{M}$ antigens, which are specific for $H$. capsulatum.

Both cultures were sent to CDC, where Dr. Leo Kaufman tested them by exoantigen and gen-probe. Diagnostic confirmation of infection by an unusual fungus suggested the need for a wide spectrum antifungal. Previous positive experience with itraconazole for treatment of children with tinea capitis led the authors to choose this drug. Treatment with oral itraconazole $100 \mathrm{mg} /$ day was started and after three months all lesions had disappeared leaving residual hypochromic macules. 


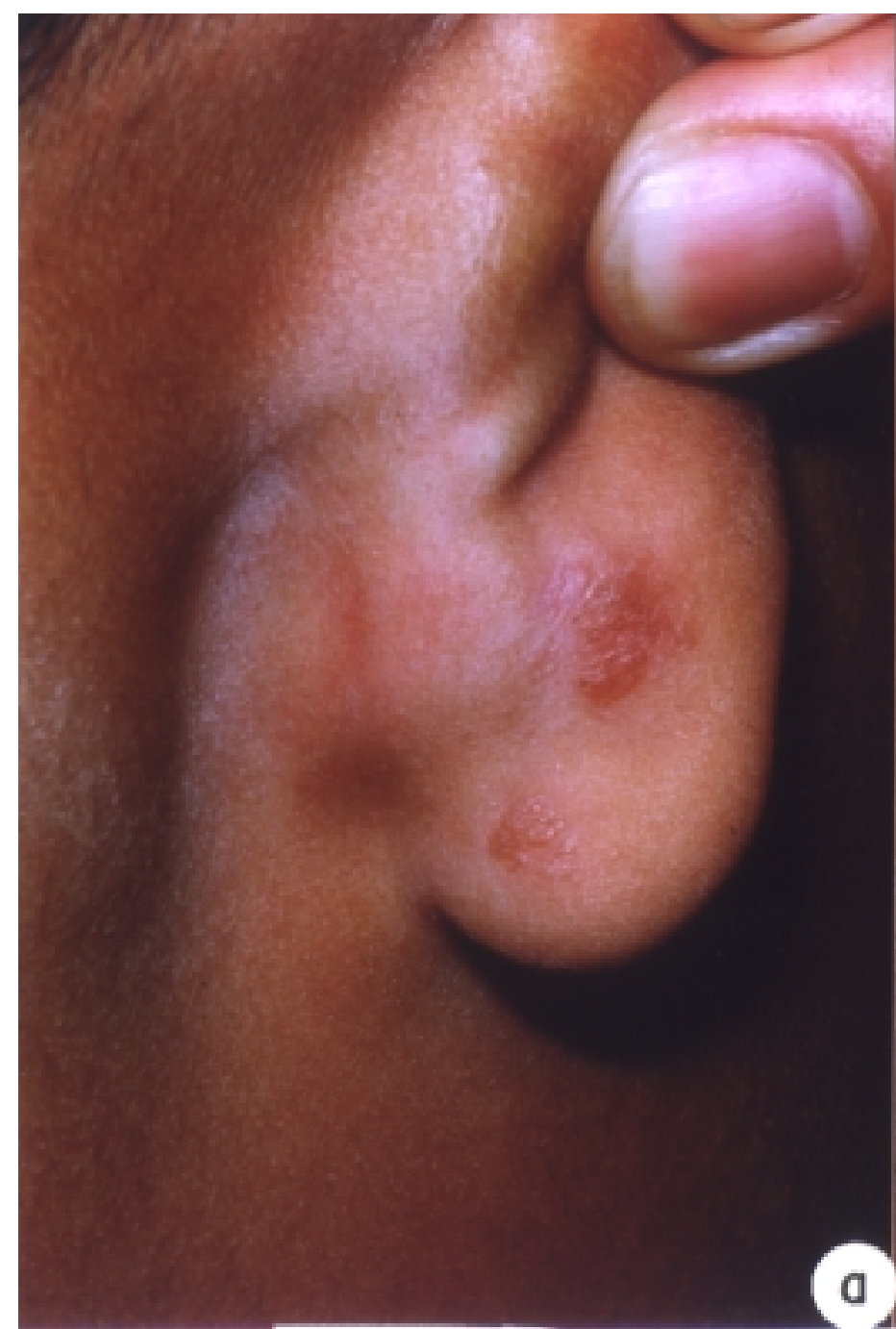

Fig. 3 - Patient G.M.L. Before (a) and after (b) treatment.

\section{DISCUSSION}

Clinic, histologic and mycologic characteristics of the present case are unusual. Disseminated cutaneous lesions observed in an immunocompetent child suggest the occurrence of secondary dissemination, most probably from a pulmonary primary site, not identified by clinical nor radiologic examination. In 1955, LACAZ et al. ${ }^{12}$ reported a case of histoplasmosis in a child from Bahia/Brazil. At that time only nine cases of histoplasmosis had been diagnosed in Brazil. The child presented hepatosplenic lesions and fungi were found in liver and spleen at autopsy.

According to STUDDARD et al. ${ }^{18}$, cutaneous histoplasmosis normally presents two types of lesions: small papules which gradually become ulcerated and surrounded by erythematous and scaly skin and ulcers with elevated borders. In the present patient erythemato-violaceous, infiltrated, pea-sized cutaneous nodules surrounded by a hypocromic halo were observed. Lesions were present on the upper and lower limbs, outer ear, face and buttocks. General health was otherwise unchanged. This clinical manifestation, atypical for cutaneous histoplasmosis, led to different diagnostic hypothesis, such as numular eczema, lymphomatoid papulosis, sarcoidosis and persistent reaction to insect bite. Diagnosis was made even more difficult because of the absence of parasitic elements on histologic slides. It is well known that cutaneous histoplasmosis is easily diagnosed through skin biopsy.

Immunohistochemical reaction with anti- $H$. capsulatum antibodies is a valuable tool in the diagnosis of this disease because of its high sensitivity, as well as the quickness with which it may be carried out. PIRES D'AVILA, $1997^{15}$ reported on the high sensitivity of this method, when analyzing 12 tissue samples obtained from patients with cutaneous histoplasmosis.

Isolation of the agent on Sabouraud agar was achieved on two occasions (Fig. 6), excluding the possibility of contamination. The isolated fungus was first thought to be Sepedonium sp., a contaminant. Impossibility to demonstrate fungal structures in histologic examination contributed to that hypothesis. Tuberculated, hyaline or brownish col- 


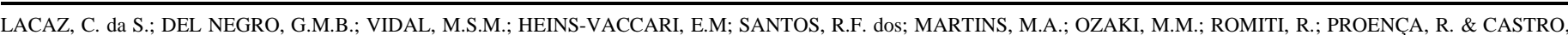
L.G.M. de - Atypical disseminated cutaneous histoplasmosis in an immunocompetent child, caused by an "aberrant" variant of Histoplasma capsulatum var. capsulatum. Rev. Inst. Med. trop. S. Paulo, $41(3):$ 195-202, 1999

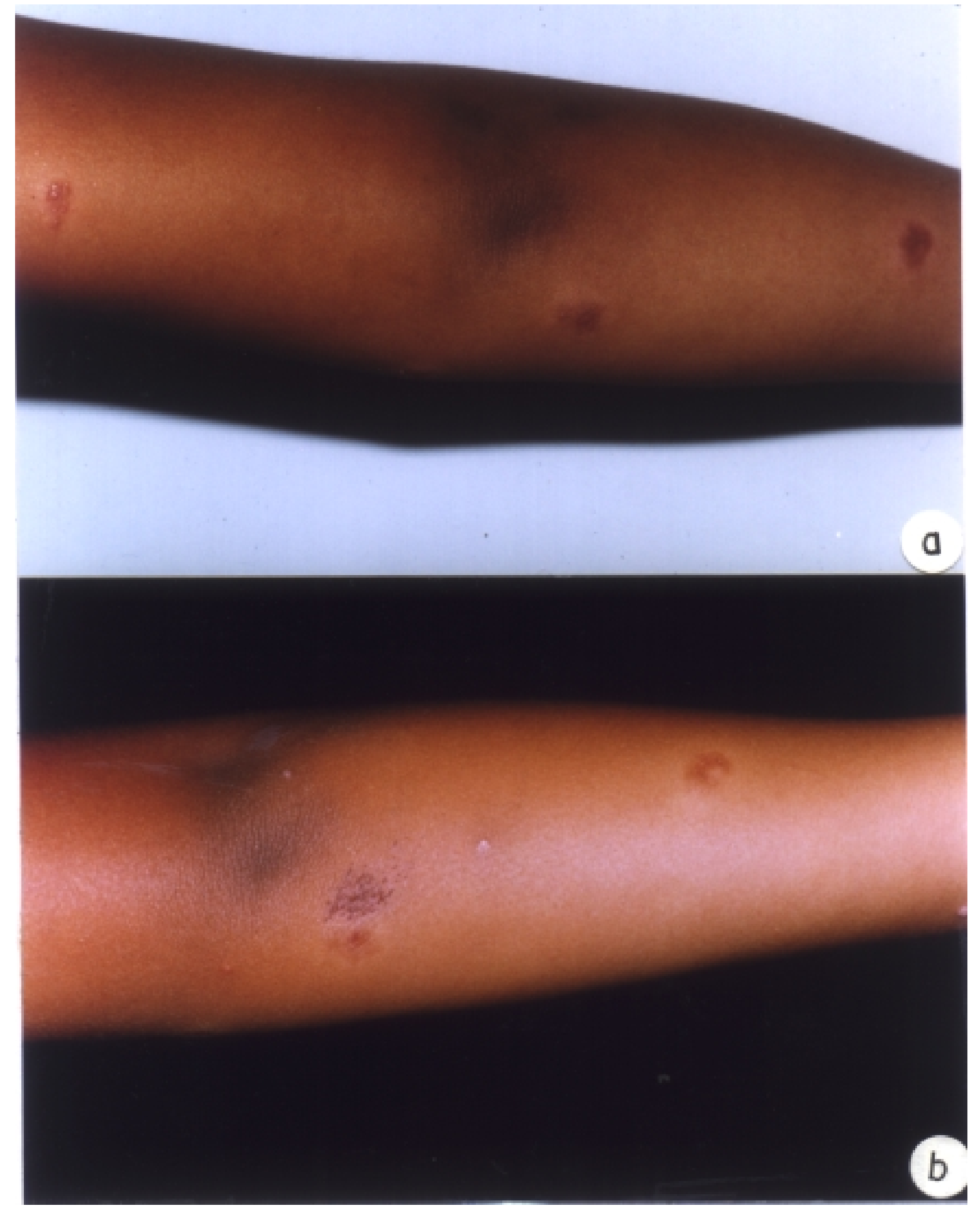

Fig. 4 - Patient G.M.L. Before (a) and after (b) treatment.

ored macroconidia, larger than would be expected for $H$. capsulatum were observed (Fig. 7).

Specific immunochemical tests to differentiate fungi from Histoplasma genus were developed by STANDARD \& KAUFMAN, $1976^{17}$, who used filamentous forms of $H$. capsulatum var. capsulatum, $H$. capsulatum var. duboisii, H. capsulatum var. farciminosum, Arthroderma tuberculatum, Chrysosporium keratinophilum, Corynascus (Thielavia) sepedonium and their specific antisera. DID showed that Histoplasma spp. samples were unique in producing $\mathrm{H}$ and $\mathrm{M}$ antigens. 


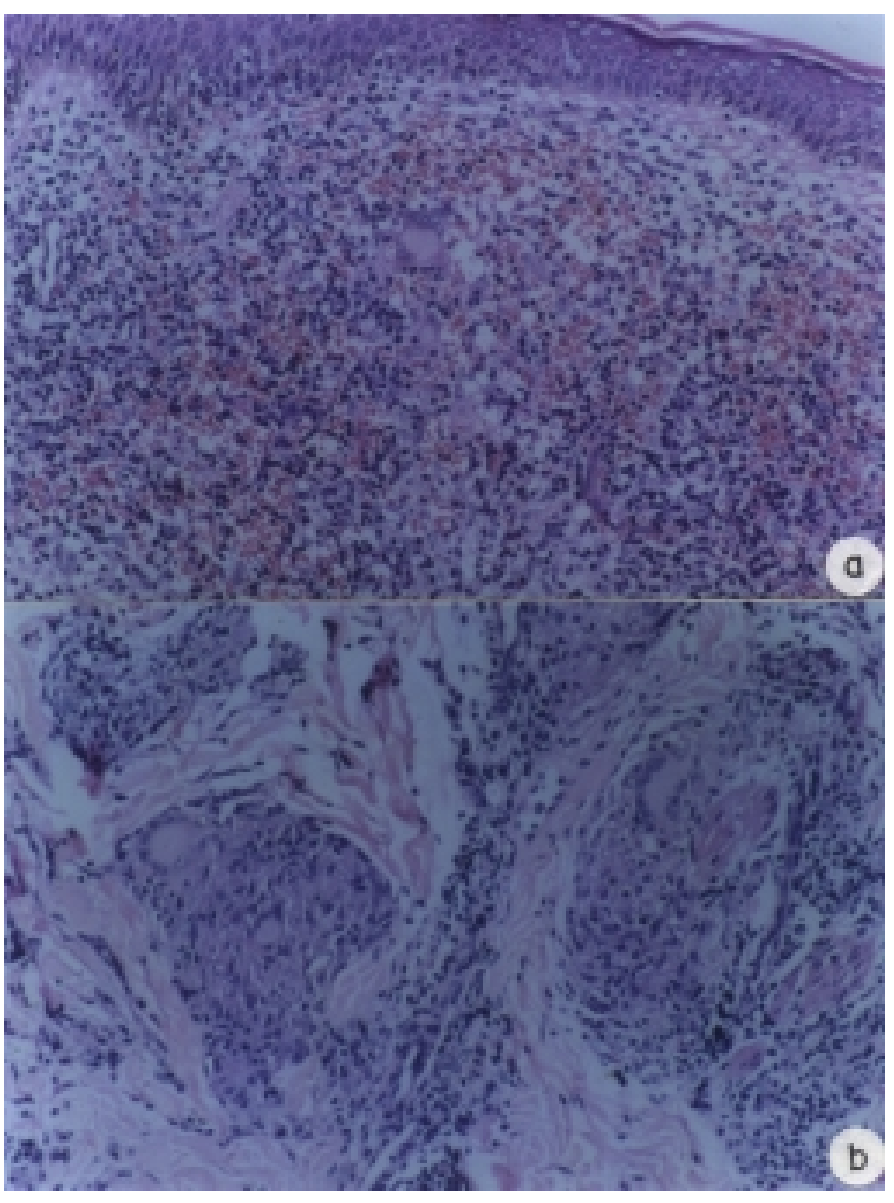

Fig. 5 - a) HE: skin biopsy - Superior dermis with well defined diffuse granulomatous inflammatory infiltrate. b) HE: skin biopsy - Deep dermis disclosing well organized tuberculoid granulomas.

Detection of a precipitation band in one case of acute adiaspiromycosis observed in Bahia/Brazil, by BARBOSA et al., $1997^{2}$ was suggestive to Dr. Leo Kaufman of concomitant histoplasmosis and adiaspiromycosis infection or an early infection by $H$. capsulatum var. capsulatum.

Antigen from one of the isolated samples was obtained by KAUFMAN \& STANDARD's technique ${ }^{8}$. It was tested by DID against serum from the patient and rabbit anti-H. capsulatum var. capsulatum hyperimmune serum. Two precipitation bands identical to the ones observed with H.capsulatum antigen were detected using rabbit serum, while no bands were observed with the patient's serum (Fig. 8).

Immunoblotting of patient's serum disclosed a fraction of approximately $94 \mathrm{kDa}$. According to ZANCOPÉ et al. ${ }^{21}$, this fraction corresponds to a glycoprotein present in histoplasmin. Studies of FAVA, $1996^{6}$, using the polysaccharide antigen from $H$. capsulatum obtained according to NORDÉN's technique, $1951^{13}$, demonstrated that this fraction is responsible for the positivity of histoplasmin reaction. According to DEEPE JR \& DUROSE, $1995^{4}$, this band can stimulate a cellular type immune response in Balb c mice, otherwise not providing protection against infection by H.capsulatum.

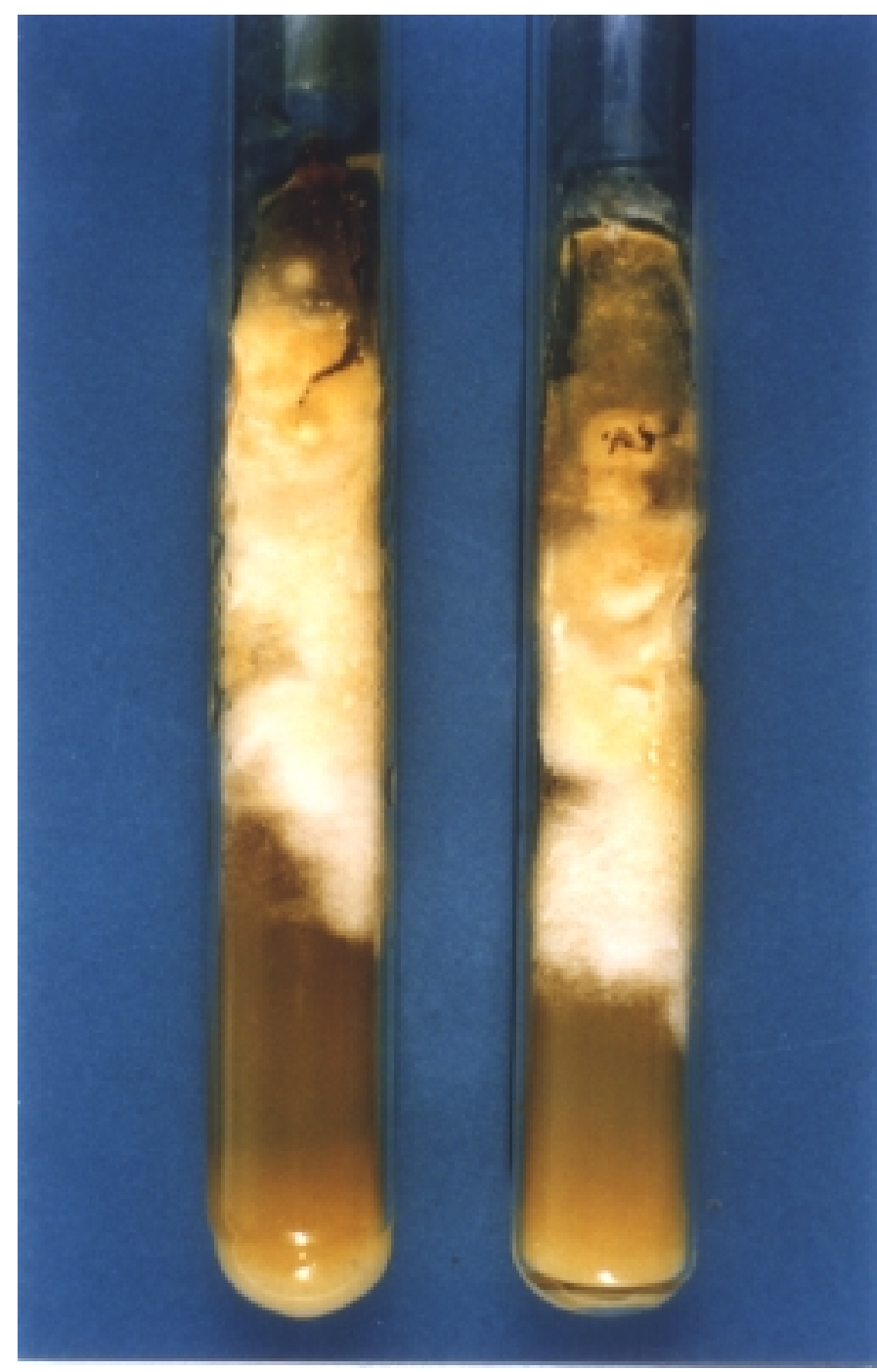

Fig. 6 - Histoplasma capsulatum var. capsulatum. Macroscopic appearance in Sabouraud agar after 30 days at room temperature.

GOMEZ et al., $1997^{7}$, utilizing ELISA to detect a specific antigen in the histoplasmosis serum, showed that this technique has great sensitivity and higth specificity, giving yet another methodology helpful in diagnosis of this fungal infection.

In 1978, KAUFMAN \& STANDARD 9 extracted antigens from Coccidioides immitis, H. capsulatum, Sepedonium sp, Chrysosporium karatinophilum, Malbranchea sp and Arthroderma tuberculatum. Immunodiffusion test disclosed high sensitivity and specificity for diagnosis of coccidioidomycosis and histoplasmosis. In the present work, patient's serum did not react when tested against antigens obtained from the infecting fungal sample, a noteworthy finding.

Several reports point out the emergence of fairly atypical strains of H. capsulatum var. capsulatum. These strains that show phenotypic changes could interfere on host-parasite interaction (EISSENBERG \& 


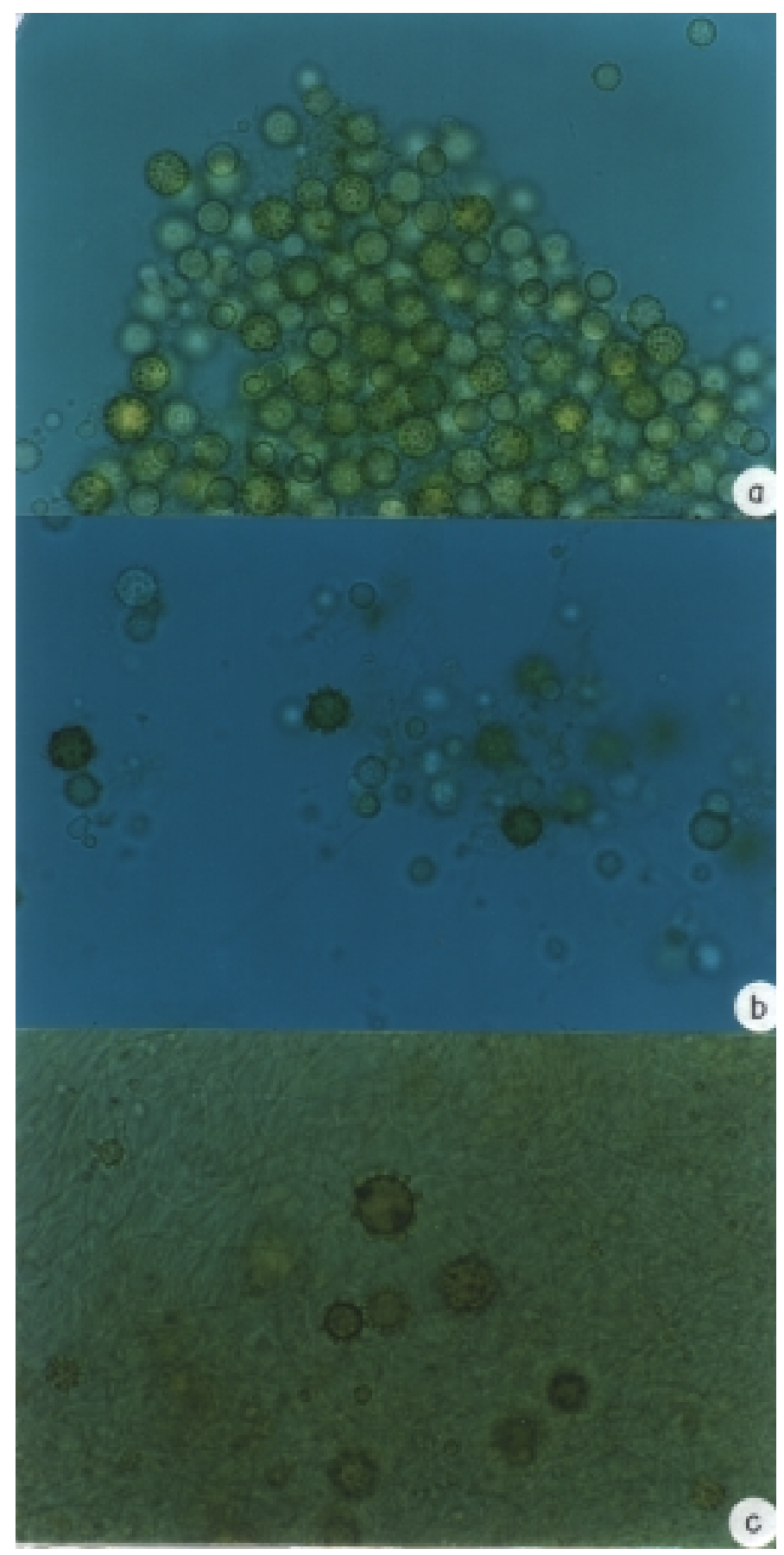

Fig. 7 - Microscopic characteristics in Sabouraud agar after 30 days, growth at room temperature. Hyaline and some pigmented tuberculate macroconidia. a), b) 400X; c) 630X.

GOLDMAN, $1991^{5}$, KEATH et al., $1992^{10}$ and KERSULYTE et al., $\left.1992^{11}\right)$.

SUTTON et al., $1997^{19}$ referred an "aberrant" variety of Histoplasma capsulatum var. capsulatum. This isolate was obtained from right elbow synovial liquid of a patient with histoplasmosis from Kansas, USA. Colonies grown on Sabouraud agar were smooth, not possessing

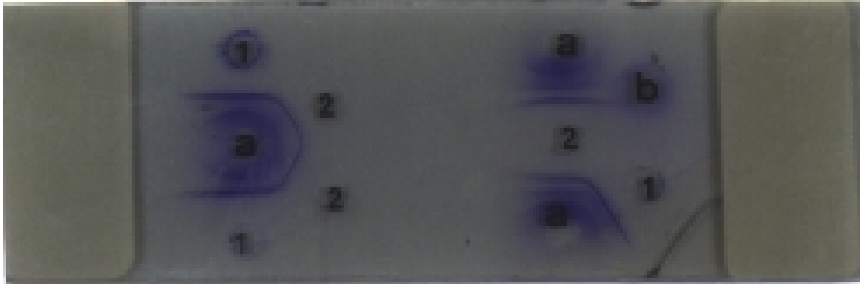

Fig. 8 - Double Immunodiffusion test, exhibiting identical $\mathrm{H}$ and $\mathrm{M}$ bands in both $H$. capsulatum antigens.

1) $H$. capsulatum metabolic antigen with $\mathrm{H}$ and $\mathrm{M}$ fractions.

2) Exoantigen obtained from the sample isolated from patient's biopsy.

a) Polyclonal anti- $H$. capsulatum rabbit serum.

b) Patient's serum.

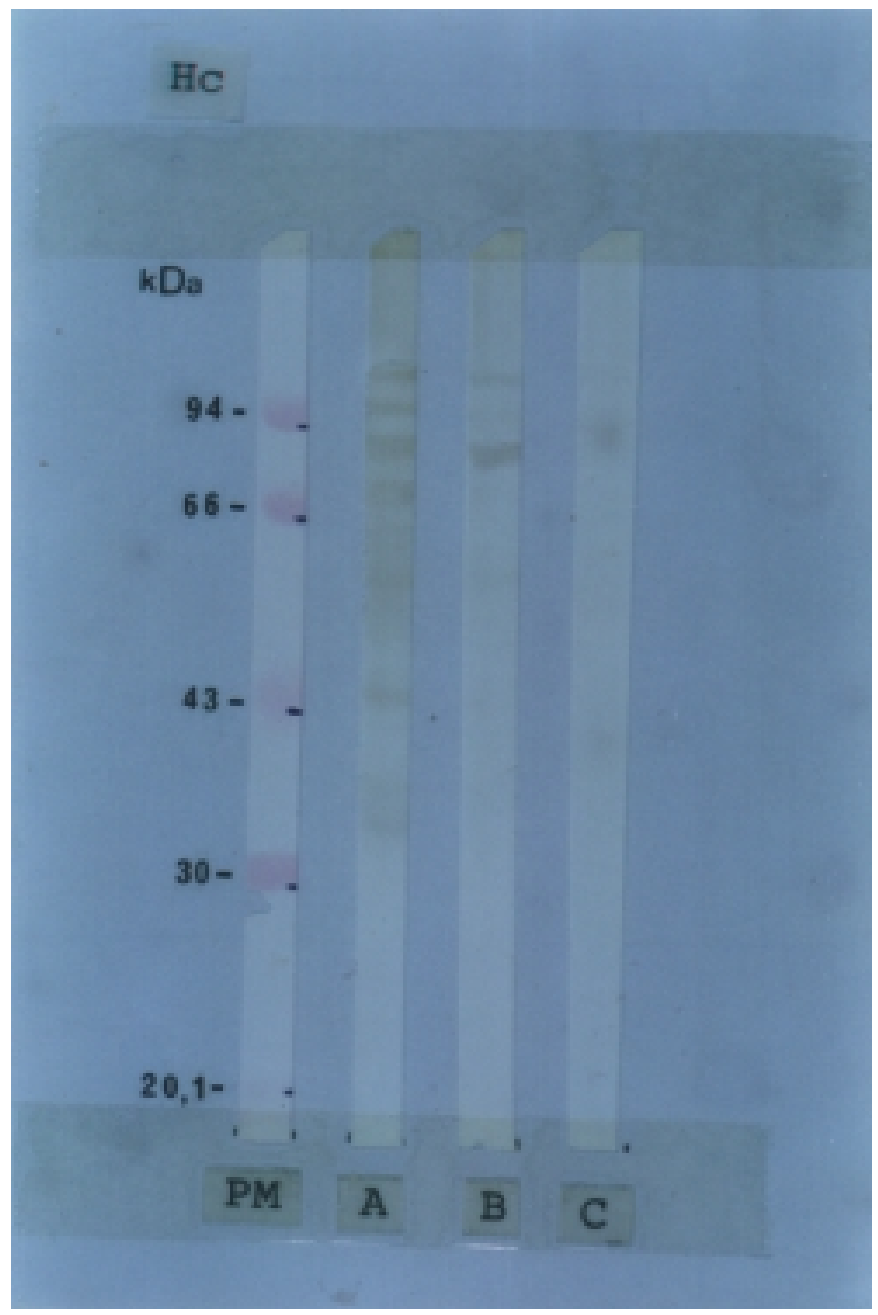

Fig. 9 - Immunoblotting with $H$. capsulatum metabolic antigen showing the presence of 94 $\mathrm{kDa}$ band.
a) Patient's serum
b) Control serum presenting positive reaction for histoplasmosis.
c) Negative control serum.
PM) Molecular weight pattern.

characteristic macroconidia of $H$. capsulatum var. capsulatum. Identification was confirmed by DNA-probe. 


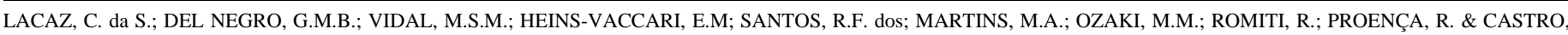
L.G.M. de - Atypical disseminated cutaneous histoplasmosis in an immunocompetent child, caused by an "aberrant" variant of Histoplasma capsulatum var. capsulatum. Rev. Inst. Med. trop. S. Paulo, $41(3):$ 195-202, 1999

\section{RESUMO \\ Histoplasmose cutânea disseminada atípica em criança imunocompetente, causada por uma variante "aberrante" de Histoplasma capsulatum var. capsulatum}

O presente trabalho registra caso de histoplasmose em paciente de 5 anos, HIV negativo, natural e procedente da cidade de São Paulo, com lesões cutâneas não diagnosticadas clinicamente. Exame histopatológico negativo para infecção fúngica. Cultivos em duas ocasiões, positivos para Histoplasma capsulatum var. capsulatum (amostras 361 e 387). Sorologia negativa para anticorpos anti-Histoplasma capsulatum e Paracoccidioides brasiliensis pelas provas de Imunodifusão dupla e Contraimunoeletroforese. Ensaio imunoenzimático pesquisando o antígeno polissacarídico específico, negativo. A obtenção do exoantígeno de uma das amostras permitiu, através de provas de Imunodifusão, com soro de coelho anti-Histoplasma capsulatum var. capsulatum, detectar duas bandas de precipitação. Registre-se a negatividade da reação de Imunodifusão dupla do soro do paciente face ao exoantígeno produzido com a amostra dele isolada. Através da reação de Immunoblotting foi identificada uma fração com peso molecular de aproximadamente 94 $\mathrm{kDa}$, além de outras. Os dois cultivos foram enviados ao Prof. Leo Kaufman, CDC, Atlanta, USA, o qual identificou as duas amostras como Histoplasma capsulatum var. capsulatum, através de provas de Imunodifusão dupla com os respectivos exoantígenos e sonda específica do fungo (DNA-probe). As colorações específicas para fungos, nos tecidos, foram negativas, incluindo prova de Imunoperoxidase para Histoplasma capsulatum var.capsulatum, a negatividade das provas sorológicas para histoplasmose clássica e o próprio aspecto clínico das lesões cutâneas eritêmato-violáceas infiltradas, mostram que o caso em apreço é realmente inusitado, correspondendo o cultivo a uma "variante aberrante" do Histoplasma capsulatum var. capsulatum. Face ao diagnóstico micológico de histoplasmose clássica, o paciente foi tratado com itraconazol $100 \mathrm{mg} / \mathrm{dia}$, durante três meses, com regressão total das lesões.

\section{ACKNOWLEDGMENTS}

The authors are indebted to Dr. Leo Kaufman Ph.D., Chief, Mycoses Immunodiagnostic Lab., Division of Bacterial \& Mycotic Diseases, CDC, Atlanta USA, for identification of the strains.

\section{REFERENCES}

1. ALVES, K.S. - Histoplasmose disseminada e síndrome de imunodeficiência adquirida. Estudo clínico-laboratorial de 28 casos. São Paulo 1996. (Dissertação de Mestrado - Faculdade de Medicina da Universidade de São Paulo).

2. BARBOSA, A.A.; LEMOS, A.C.M. \& SEVERO, L.C. - Acute pulmonary adiaspiromycosis. Report of three cases and a review of 16 other cases collected from literature. Rev. iberoamer. Micol., 14: 177-180, 1997.

3. BORGES, A.S.; FERREIRA, S.M.; SILVESTRE, M.T.A.; NISHIOKA, S.A. de \& ROCHA, A. - Histoplasmose em pacientes imunodeprimidos. Estudo de 18 casos observados em Uberlândia, Minas Gerais. Rev. Soc. bras. Med. trop., 30: 119-124, 1997.

4. DEEPE JR., G.S. \& DUROSE, G.G. - Immunological activity of recombinant H antigen from Histoplama capsulatum. Infect. Immun., 63: 3151-3157, 1995.
5. EISSENBERG, G.L. \& GOLDMAN, W.E. - Histoplasma variation and adaptive strategies for parasitism new perspectives on histoplasmosis. Clin. Microbiol. Rev., 4: 411 421, 1991.

6. FAVA, S. di C. - Contribuição ao estudo da reação intradérmica de histoplasmina. Padronização de antígeno polissacáride e comparação com histoplasmina clássica (antígeno filtrado) através de inquérito epidemiológico. São Paulo, 1996 (Tese de Doutoramento - Faculdade de Medicina da Universidade de São Paulo).

7. GOMEZ, B.L.; FIGUEROA, J.I.; HAMILTON, A J. et al. - Development of a novel antigen detection test for histoplasmosis. J. clin. Microbiol., 35: 2618-2622, 1997.

8. KAUFMAN, L. \& STANDARD, P. - Improved version of the exoantigen test for identification of Coccidioides immitis and Histoplasma capsulatum cultures. J. clin. Microbiol., 8: 42-45, 1978.

9. KAUFMAN, L. \& STANDARD, P.G. - Specific and rapid identification of medically important fungi by exoantigen detection. Ann. Rev. Microbiol., 41: 209-225, 1987.

10. KEATH, E.J.; KOBAYASHI, G. S. \& MEDOFF, G. - Typing of Histoplasma capsulatum by restriction fragment length polymorphisms in a nuclear gene. J. clin. Microbiol., 30: 2104-2107, 1992.

11. KERSULYTE, D.; WOODS, J.P.; KEATH, E.J.; GOLDMAN, E.W. \& BERG, D.E. Diversity among clinical isolates of Histoplasma capsulatum detected by polymerase chain reaction with arbitrary primers. J. Bact., 174: 7075-7079, 1992.

12. LACAZ, C. da S.; DEL NEGRO, G.; LUISI, A. \& CASTRO, R.M. - Histoplasmose na infância. Comentários sobre um caso. Revisão da literatura nacional. Novos dados sobre a histoplasmina em nosso meio. Rev paul. Med., 47: 495-509, 1955.

13. NORDÉN, A. - Sporotrichosis: clinical and laboratory features and a serologic study in experimental animals and humans. Acta path. microbiol. scand., (suppl. 89): 1-119, 1951.

14. PADHYE, A.A.; SMITH, G.; MCLAUGHLIN, D.; STANDARD, G.P. \& KAUFMAN, L. - Comparative evaluation of a chemiluminescent DNA probe and an exoantigen test for rapid identification of Histoplasma capsulatum. J. clin. Microbiol., 30: 3108-3111, 1992

15. PIRES D'ÁVILA, S.C.G. - Contribuição ao estudo histopatológico e imunohistoquímico da histoplasmose disseminada na pele e na mucosa oral em aidético. Rev. Soc. bras. Med. trop., 30: 429-430, 1997.

16. ROCHA, M.M. \& SEVERO, L.C. - Histoplasmose disseminada em pacientes com Síndrome de Imunodeficiência Adquirida (SIDA). Estudo de 25 casos. Rev. Inst. Med. trop. S. Paulo, 36: 167-170, 1994.

17. STANDARD, P.G. \& KAUFMAN, L. - Specific immunological test for the rapid identification of members of the genus Histoplasma. J. clin. Microbiol., 3: 191-199, 1976.

18. STUDDARD, J.; SNEED, W.F.; TAYLOR JR., M.R. \& CAMPBELL, G.D. - Cutaneous histoplasmosis. Amer. Rev. resp. Dis., 113: 689-693, 1976.

19. SUTTON, A.D.; PADHYE, A.A.; STANDARD, P.G. \& RINALDI, M.G. - An aberrant variant of Histoplasma capsulatum. J. clin. Microbiol., 35: 734-735, 1997.

20. WHEAT, L.J.; CONNOLLY-STRINGFIELD, P.A ; BAKER, R.L. et al.- Disseminated histoplasmosis in the acquired immune deficiency syndrome: clinical findings, diagnosis and treatment and review of the literature. Medicine (Baltimore), 63: 361-374, 1990

21. ZANCOPÉ-OLIVEIRA, M.R.; BRAGG, S.L.; HUST, S.F.; PERALTA, J.M. \& REISS, E. - Evaluation of cation exchange chromatography for the isolation of M glycoprotein from histoplasmin. J. med. vet. Mycol., 31: 29-41, 1993.

Received: 16 December 1998

Accepted: 26 March 1999. 